\title{
The HrpG/HrpX Regulon of Xanthomonads-An Insight to the Complexity of Regulation of Virulence Traits in Phytopathogenic Bacteria
}

\author{
Doron Teper ${ }^{1, *}$, , Sheo Shankar Pandey ${ }^{2}\left[\right.$ and Nian Wang ${ }^{2, *}$ \\ 1 Department of Plant Pathology and Weed Research, Agricultural Research Organization (ARO)-Volcani \\ Center, Rishon LeZion 7505101, Israel \\ 2 Citrus Research and Education Center, Department of Microbiology and Cell Science, \\ Institute of Food and Agricultural Sciences, University of Florida, Lake Alfred, FL 33850, USA; \\ sshankar.pandey@ufl.edu \\ * Correspondence: doront@volcani.agri.gov.il (D.T.); nianwang@ufl.edu (N.W.)
}

check for

updates

Citation: Teper, D.; Pandey, S.S.;

Wang, N. The HrpG/HrpX Regulon of

Xanthomonads-An Insight to the

Complexity of Regulation of Virulence

Traits in Phytopathogenic Bacteria.

Microorganisms 2021, 9, 187.

https://doi.org/10.3390/

microorganisms 9010187

Received: 15 December 2020

Accepted: 13 January 2021

Published: 16 January 2021

Publisher's Note: MDPI stays neutral with regard to jurisdictional clai$\mathrm{ms}$ in published maps and institutional affiliations.

Copyright: (C) 2021 by the authors. Licensee MDPI, Basel, Switzerland. This article is an open access article distributed under the terms and conditions of the Creative Commons Attribution (CC BY) license (https:// creativecommons.org/licenses/by/ $4.0 /)$.

\begin{abstract}
Bacteria of the genus Xanthomonas cause a wide variety of economically important diseases in most crops. The virulence of the majority of Xanthomonas spp. is dependent on secretion and translocation of effectors by the type 3 secretion system (T3SS) that is controlled by two master transcriptional regulators HrpG and HrpX. Since their discovery in the 1990s, the two regulators were the focal point of many studies aiming to decipher the regulatory network that controls pathogenicity in Xanthomonas bacteria. HrpG controls the expression of HrpX, which subsequently controls the expression of T3SS apparatus genes and effectors. The HrpG/HrpX regulon is activated in planta and subjected to tight metabolic and genetic regulation. In this review, we cover the advances made in understanding the regulatory networks that control and are controlled by the HrpG/HrpX regulon and their conservation between different Xanthomonas spp.
\end{abstract}

Keywords: Xanthomonas; HrpG; HrpX; type 3 secretion system; regulatory networks; phytopathogenic bacteria; transcriptional regulators

\section{Introduction}

Xanthomonas is a large genus of gamma-proteobacteria. Xanthomonas isolates are mostly plant-associated, and many are important plant pathogens that cause devastating effects on yield [1]. Xanthomonas species harbor extremely high host specificity and together infect hundreds of crops [1,2]. Because of their significant economic impact, Xanthomonas bacteria were extensively studied in the past three decades to achieve a mechanistic understanding of virulence functions and host specificity determinants. Most pathogenic Xanthomonas spp. facilitate pathogenic interactions with their hosts by secreting and delivering effector proteins into the host cell via the type 2 and 3 secretion systems [3]. Type 3 secretion system and secreted effectors are subjected to tight transcriptional regulation mediated by the two master regulators HrpG and HrpX. Here, we review the environmental factors and regulatory networks associated with virulence regulation in xanthomonads controlled by the HrpG/HrpX regulon.

\section{Virulence and Occurrence of Secretion Systems in Xanthomonas spp.}

Xanthomonas species encode six different protein secretion systems (types 1 to 6) and abundance, phylogenetic lineages, and the number of copies of each protein secretion system varies among species or pathotypes, and occurrence of all six secretion systems in a single species is common [2,4]. Type 6 and type 4 secretion systems (T4SS and T6SS) of various lineages are found in many species and have been suggested to play a role in the persistence of the bacteria in the environment. Chromosome-encoded T4SS 
of Xanthomonas citri subsp. citri (Xcci) was reported to provide the capacity of contactdependent bacterial killing through the delivery of toxins to cells of neighboring bacteria [4], whereas T6SS was identified to prevent predation by the soil amoeba through an unknown mechanism [5]. Most Xanthomonas strains harbor two type 2 secretion systems (T2SS) classified as $x c s$ and $x p s$. The contribution of the $x c s$ T2SS to pathogenicity on plants or persistence in the environment is poorly understood, and the system is absent in several Xanthomonas species such as Xanthomonas oryzae pv. oryzae (Xoo) [2]. The xps T2SS is conserved in the genomes of all sequenced Xanthomonas species and is required for full virulence of Xoo, Xanthomonas euvesciatoria (Xeu), and Xcci [6-8]. The xps T2SS enables the secretion of numerous secreted hydrolases [9]. Secreted hydrolases such as xylanase, cellulases, esterases, and pectinases function as virulence factors in many Xanthomonas species and are required for full virulence on host plants [9-12]. However, cell wall hydrolysis by these hydrolases can also elicit immune responses through host recognition of damage-associated molecular patterns [13,14].

Flagellar and injectisome type 3 secretion systems are abundant among Xanthomonas species [3]. The flagellar T3SS (FT3SS) is required for motility, biofilm formation, and chemotactic movement [15-17]. Disruption of the FT3SS affects entry and infectivity of the bacteria and is mostly associated with the epiphytic stage of Xanthomonas life cycle [1,17]. Injectisome type 3 secretion system (T3SS) enables the translocation of effector proteins from bacteria to eukaryotic cells which affect host signaling and metabolism [18]. Many bacteria utilize this system to establish pathogenic or symbiotic interactions with their eukaryotic hosts. A hypersensitive reaction and pathogenicity 2 ( $h r p 2$ ) family injectisome T3SS $[19,20]$ is found in the majority of pathogenic Xanthomonas strains and is considered as one of the main pathogenicity factors of the bacteria [3,21]. Almost all pathogenic group 2 Xanthomonas species harbor T3SS genes that are localized in a $\sim 30 \mathrm{~kb}$ chromosomal pathogenicity island and composed of approximately 20 core structural component coding genes in six transcriptional units (A to F), while additional T3SS accessory and effector coding genes within the pathogenicity island vary between species or pathotypes [22] (Figure 1). Disruption of any key structural component of the T3SS results in the inability to cause disease, colonize host plant, and induce hypersensitive response (HR) in resistant host varieties [3]. In addition, hrp-dependent pathogenic Xanthomonas strains encode on average 25-35 T3SS effectors (T3Es) that were reported to function in manipulating host immune signaling, liquid accumulation in the intercellular spaces, and nutrient accessibility $[2,3,21]$. The biochemical properties, host targets, and functions of T3Es were previously reviewed $[2,3,21]$. Several group 2 xanthomonads, such as X. maliensis, $X$. cannabis, and multiple $X$. arboricola strains that lack T3SS or harbor a reduced arsenal of T3Es were identified in the past decade [23-25]. These bacteria display reduced growth in planta, do not cause symptoms in host plants, and are considered as commensal strains. A direct correlation between pathogenicity to the occurrence of $h r p 2$ T3SS in group 1 xanthomonads is less apparent and appears to be species-specific; the T3SS is required for full pathogenicity of X. translucens strains but is absent in sugarcane pathogenic bacteria X. albilineans and X. sacchari [1]. In addition, the T3SS genomic islands of group 1 xanthomonads share low homology and altered gene composition compared with group 2 xanthomonads, indicating that T3SS was acquired independently in these strains [26] (Figure 1). For instance, the hrpF/nolX gene that encodes the T3SS translocon in group 2 xanthomonads is absent in group 1 that harbors an alternative translocon coding gene, traT [27]. 


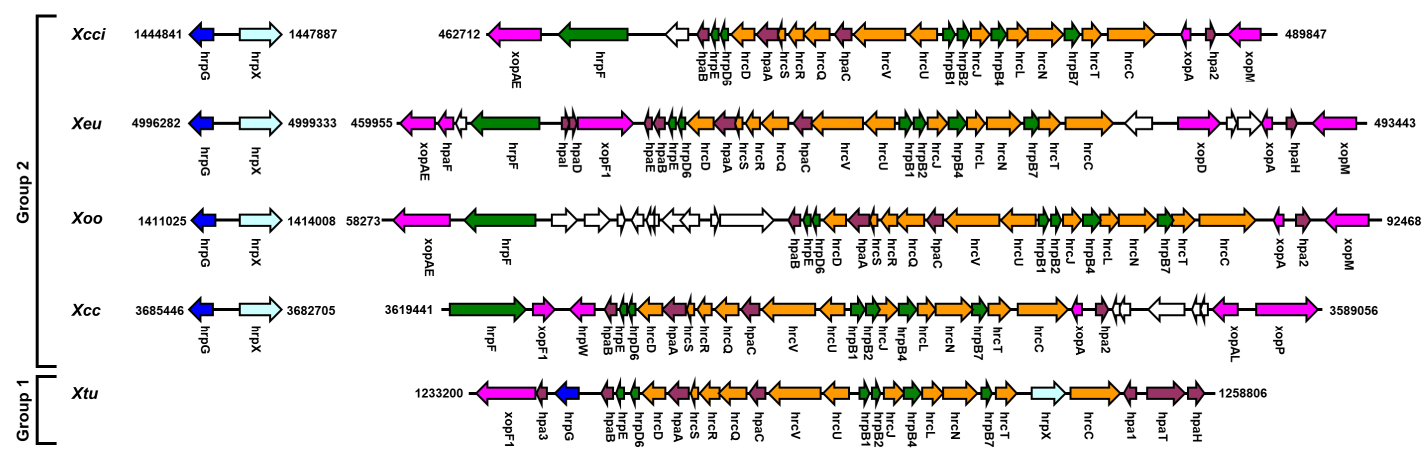

Figure 1. Genetic organization of the hypersensitive reaction and pathogenicity ( $h r p$ ) gene cluster and the $h r p G / h r p X$ coding regions in Xanthomonas spp. Schematic representation of the gene clusters of group 2 xanthomonads X. citri subsp. citri (Xcci, strain 306), X. euvesicatoria (Xeu, strain 85-10), X. oryzae pv. oryzae (Xoo, strain KACC10331), and X. campestris pv. campestris (Xcc, strain 8004), and group 1 Xanthomonas X. translucens pv. undulosa (Xtu, strain 4699). The location of the indicated regions within their respective genomes is stated.

\section{HrpG and HrpX Are Key Virulence Regulators in Xanthomonas spp.}

The ability to cause disease in host plants in hrp-dependent Xanthomonas spp. is dependent on two transcriptional regulators- HrpX and HrpG [3]. HrpX was first identified in the early 1990s in a transposon screen in X. campestris pv. campestris (Xcc) [28] and soon after was found to have similar functions in other Xanthomonas spp. [29,30]. The hrpX gene encodes a $\sim 476$ amino acids (AA) (sizes may vary between species, mostly due to alternative prediction of the start codon) AraC-type bacterial transcriptional regulator [31]. Disruption of hrpX in Xanthomonas bacteria that harbor T3SS completely abolished the ability to cause disease, colonize the plant host, or induce HR in resistant or non-host plants in a similar manner to disruption of structural components of the T3SS [3]. Further analyses demonstrated that transcriptional regulation of the six T3SS transcriptional operons and multiple T3Es is dependent on HrpX [22,30,32-34], thus establishing HrpX as a master regulator of $h r p$-dependent protein secretion.

HrpG was identified in a screen for virulence-associated mutants using N-methyl$\mathrm{N}^{\prime}$-nitro-N-nitrosoguanidine mutagenesis in Xeu [35]. Similarly to hrpX, inactivation or deletion of $h r p G$ eliminates the ability of the bacteria to induce HR in resistant or non-host plants, or cause disease and colonize host plants [35-37]. hrpG inactivation mutants also display a significant reduction in the transcription of T3SS and T3Es coding genes and hrpX itself [35-37] (Figure 2). In vitro studies showed that HrpG directly binds to the promoter region of $h r p X$ and induces the transcription of $h r p X$, indicating that $h r p X$ is a direct target of HrpG [38,39] (Figure 2). hrpG encodes a 260-267 AA orphan OmpR family transcription regulator [35]. While HrpG structure was not experimentally determined, the mechanistic function was characterized by several key point mutations that affected its activity. Most OmpR regulators are part of a two-component system and are encoded in an operon or in the proximity of a histidine kinase that activates OmpR protein by phosphorylation [40]. HrpG harbors a conserved aspartate residue at position 60 (of Xcci and Xeu HrpG) that serves as a phosphorylation site; however, no histidine kinase gene is encoded in proximity to $h r p G$. HrpG D60N substitution mutant of Xcci is not phosphorylated in hrp-inducing conditions and cannot complement the $h r p G$ mutant [41], suggesting that HrpG is activated through phosphorylation by an unknown kinase. The mutation that resulted in R210C substitution in Xcci HrpG produced a dominantly negative inactive variant [38]. This mutant variant was not able to complement the $h r p G$ inactivation mutant and reduced the expression levels of HrpG associated genes and effector delivery when introduced into wild-type Xcci [38]. In vitro assays identified that this HrpG variant can still bind to the $h r p X$ promoter but is unable to induce the transcription of $h r p X$ [38]. Random mutagenesis conducted in Xeu hrpG identified three constitutively active variants (corresponding to 
AA substitution of E44K, H194R, D199N), which induced the expression of hrp genes in non-inducing media and caused enhanced HR in resistant plants [42]. The mechanism that enables the constitutive activity by these variants remains elusive.

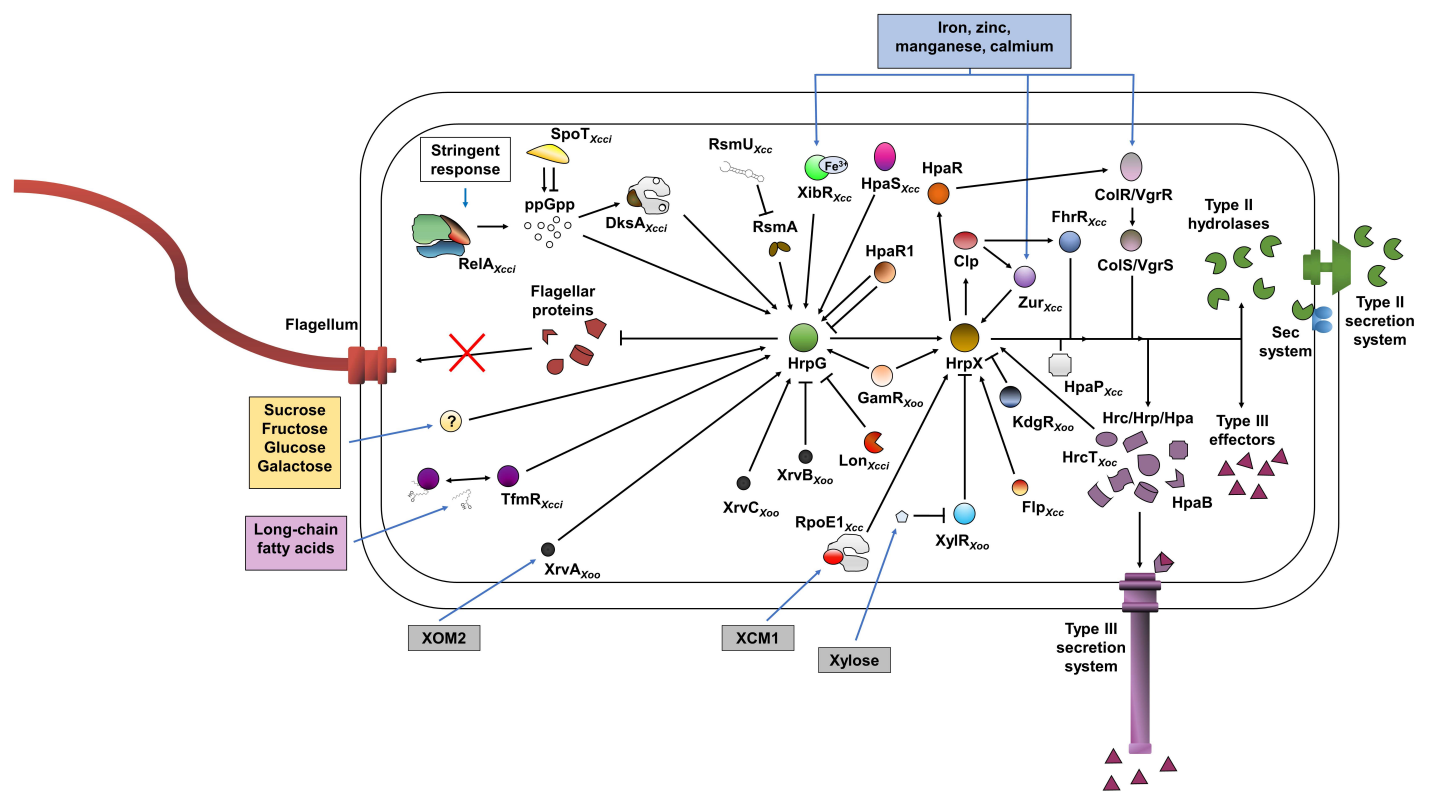

Figure 2. Schematic representation of the metabolic and genetic regulation of $h r p G$ and $h r p X$ in Xanthomonas. Metabolites and environmental cues are represented in rectangles. Arrows and " $\dashv$ " signs indicate that a protein promotes or inhibits the target, respectively, based on transcriptional or functional analyses. If the analysis was based on data derived from specific Xanthomonas species, it is marked at the bottom of the represented protein names. Data represent information derived from X. euvesicatoria, X. citri subsp. citri (Xcci), X. oryzae pv. oryzae (Xoo), X. oryzae pv. oryzicola (Xoc), X. axonopodis pv. glycines and X. campestris pv. campestris $(X c c)$.

\section{Genomic Organization of $h r p G$ and $h r p X$}

$h r p G$ and $h r p X$ are found in all reported pathogenic Xanthomonas spp. with the exception of X. albilineans and X. sacchari that lack the hrp2 T3SS gene cluster [1], and they are regarded as the master regulators of the T3SS system in xanthomonads [3]. Homologs of these two regulators were found to function in a similar manner in phytopathogenic bacteria such as Ralstonia solanacearum, Burkholderia Pseudomallei, and Acidovorax citruli [19,43-46]. In group 2 Xanthomonas spp., $h r p G$ and $h r p X$ are localized in the same genomic region in a reverse orientation of one another spaced with a 760-840 intragenic region (Figure 1 and Figure S1). While $h r p G$ and $h r p X$ share high DNA sequence similarity between different species, the $h r p G-h r p X$ intragenic regions that contain their promoter elements vary between xanthomonads (Figure S1). For instance, the $h r p G$ and $h r p X$ coding regions of Xeu and Xoo share $87 \%$ and $91 \%$ DNA sequence identity, respectively (Figure S1). On the other hand, the $h r p G-h r p X$ intragenic regions of Xeu and Xoo share 67\% DNA sequence identity (Figure S1). The variations in the $h r p G-h r p X$ intragenic regions suggest that $h r p X$ and $h r p G$ might be subjected to differential regulation in different Xanthomonas species.

In Xanthomonas spp. of group $1, h r p G$ and $h r p X$ are located in the $h r p 2$ T3SS genomic island [24] (Figure 1). hrpG is localized at the end of the hrp2 gene cluster, whereas $h r p X$ is in an operon with $h r c C$ that encodes the structural ring protein of the T3SS basal body [47]. As of now, besides the knowledge that $h r p G$ is somewhat required for the virulence of group $1 \mathrm{X}$. translucens [47], there's no information regarding the upstream or downstream regulatory networks that control group 1 xanthomonads $h r p G$ and $h r p X$. Therefore, all the information available in this review will only cover the HrpG/HrpX regulatory network of group 2 xanthomonads. 


\section{Downstream Targets and Regulatory Pathways Controlled by HrpG and HrpX}

HrpG and HrpX are master regulators of Xanthomonas T3SS and T3E. HrpG-mediated expression of most of T3SS and T3Es genes is dependent on $h r p X$, which is directly regulated by HrpG $[35,36]$. HrpX induces transcription by directly binding to plant-inducible promoter (PIP) box, a DNA motif of TTCGB-N15/N8-TTCGB found in cis element of five of the six structural T3SS operons and multiple T3Es [22]. The DNA-binding motif of HrpG remained elusive for years. A recent study [39] utilized ChIP-seq analysis to identify HrpG $\mathrm{Xcc}_{c}$-bound promoter sequences. The study found that HrpG physically interacted with 186 promoter elements. Promoter analysis identified a common DNA motif of $\operatorname{ATT}(\mathrm{C} / \mathrm{T})(\mathrm{C} / \mathrm{T})(\mathrm{G} / \mathrm{C} / \mathrm{A})(\mathrm{T} / \mathrm{A}) \mathrm{T}$ in the bound promoters and demonstrated direct binding in vitro. It should be noted that the study failed to demonstrate a robust correlation between the HrpG bound promoters and transcriptional induction of these targets by HrpG [39]. For instance, $h r p X$, which is hypothesized to be one of the main direct targets of HrpG, was not among the 186 promoters.

Functional studies found that accumulation of active HrpG and HrpX proteins is the main factor that controls the expression of the T3SS, and constitutive expression of either of these regulators results in the induction of the T3SS and T3E in non-inducing media, hypervirulence upon inoculation of susceptible plants and enhanced immune responses in resistant plants [3]. It was recently suggested that the regulatory network of the T3SS harbors an internal positive feedback loop in X. oryzae pv. oryzicola (Xoc), in which hrpX expression is regulated by T3SS protein HrcT [48] (Figure 2). It is unknown whether this mechanism is unique to this species or it is conserved among Xanthomonas spp.

High throughput transcriptional profiling analyses of the HrpG regulon and/or the HrpX regulon were conducted in Xeu, Xcci, and X. campestris pv. raphani (Xcr) $[36,37,49,50]$. Two independent transcriptome studies (conducted using microarray and RNA-seq) were done with $h r p G$ and $h r p X$ deletion strains of Xcci grown in plant-mimicking media [37,49]. Transcriptomic studies of Xeu and Xcr that were grown in rich media compared the wildtype strain with a strain harboring the constitutively active HrpG E44K variant ( $h r p G^{*}$ ) using cDNA-AFLP [36] and RNA-seq [50], respectively. T3SS and T3E coding genes were found to be positively regulated by HrpX or HrpG in all four studies $[36,37,49,50]$ (Figure 2). The T3SS gene hrcC and multiple T3E genes that lack plant-inducible promoter (PIP) box in their promoters were induced by HrpX and HrpG as well. However, the expression of several T3Es was not HrpG/HrpX dependent. In particular, HrpG and HrpX did not affect the expression of all four transcription activator-like effectors (TALEs) coding genes in Xcci [37,49]. Unlike most other T3Es, which were identified to be associated with suppression of host immune responses, TALEs were found to control more diverse factors such as sugar efflux and cell identity [51]. It is possible that TALEs are regulated independently of the rest of the T3Es because of their unique functions.

In addition to T3SS-associated genes, the four transcriptome analyses identified that HrpG or HrpX positively regulates a large number of genes encoding secreted hydrolases, such as endoglucanases, proteases, esterases, and pectinases [12,36,37,49,50] (Figure 2). Unlike the T3SS, the operons that encode structural components of either of the two T2SS identified in most Xanthomonas spp. were not regulated by HrpG or HrpX. Interestingly, several studies reported that HrpG or HrpX negatively regulates secreted protease activity even though a large number of genes encoding secreted peptidases are positively regulated by the two regulators $[36,52,53]$. The inconsistencies between the reported transcriptional regulations and functional activity need to be addressed.

The transcriptome analysis of Xcci identified that multiple genes associated with flagellar assembly and chemotaxis were upregulated in the hrpG mutant [37] (Figure 2). Supporting the transcriptional data, the $h r p G$ mutant demonstrated increased motility in soft agar plates [37]. The transcriptional expression of these genes was not affected in the hrpX mutant, suggesting that HrpG negatively regulates these genes independently of HrpX [37]. The bacterial flagella are recognized by the host immune system and therefore the association of flagellar shedding with bacterial virulence signaling seems reason- 
able [54]. However, the mechanism behind HrpG regulation of flagellar assembly and motility remains poorly understood.

HrpG and HrpX were reported to induce the expression of $h p a R$, which encodes a MarR family transcriptional regulator in multiple bacteria [36,37,49,50] (Figure 2). MarR proteins are ubiquitous bacterial transcriptional regulators that repress or activate transcription by binding to small ligand molecules that alter their binding affinity to operator sequences found in the promoters of their target genes [55]. Proteins of the MarR family were identified to regulate metabolic processes, antibiotic resistance, and stress responses [55,56]. The $h p a R_{X c c}$ deletion mutant was unable to colonize host plants or induce HR response in resistant plants [53]. Further analysis found that $\mathrm{HpaR}_{X c c}$ positively regulates the ColS/ColR (VgrS/VgrR) two-component system [57] that was independently identified to positively control hrp gene expression through an unknown mechanism [58-60].

\section{Metabolic Regulation of the HrpG/HrpX Regulon}

The expression and protein accumulation of HrpG and HrpX are highly dependent on the environment and the metabolic state of the bacterium. The two regulators are strongly expressed upon reaching the plant apoplast [61-65]. By utilizing GFP promoter fusions, Zhang et al. [61] demonstrated that $h r p G, h r p X$, and T3SS translocator $h r p F$ of Xeu are specifically induced upon entering tomato substomatal cavities, whereas their expression was repressed on the leaf surface.

The transcriptional expression of $h r p G, h r p X$, and their target genes in planta was examined in numerous studies which usually focused on a time frame of $24-48 \mathrm{~h}$ postinoculation [61-65]. However, several direct and indirect studies indicates that hrp expression starts much earlier, if not instantly upon the introduction of the bacteria into the plant environment. de Bernonville et al. have shown that $h r p E$ is highly induced in Xcc $4 \mathrm{~h}$ after inoculation of cabbage [64]. In addition, effector delivery monitored through CyaA reporter fusions or transcriptional expression of TALE-induced plant susceptibility gene suggests that effectors can be actively delivered by the T3SS into the host cells between 12-24 h post-inoculation [66,67].

Induction of the $h r p G / h r p X$ regulon is mediated through sensing the plant environment. Supplementing minimal media with rice extract or cabbage xylem sap almost immediately promoted the upregulation of $h r p G$ and $h r p X$ in Xoo and Xcc [64,68]. Undefined rich media such as NB and LB suppress hrp gene expression, whereas several $h r p$-inducing plant-mimicking artificial media were found to induce hrp gene expression. These defined media are of slightly acidic $\mathrm{pH}$ supplemented with trace metals, amino acids, and low molecular weight carbon sources such as mono- and di-saccharides or carbonic acids. Species specific responses were identified in different types of media: XVM1 and XVM2 media,, which are based on fructose and sucrose as a carbon source and methionine (for XVM1) or casamino acids (for XVM2) as a nitrogen source, induces hrp gene expression in pepper and citrus pathogens Xeu and Xcci $[37,69]$. XOM2, which uses xylose as a carbon source and methionine as the sole supplemented amino acid, promotes hrp expression in the rice pathogen Xoo [70]. MME and XCM2 media, which use either glutamate or succinate as the main carbon source and are supplemented with a low abundance of casamino acids and magnesium (in XCM2), were found to be effective for hrp expression in Xcc [71]. The differential responses of different Xanthomonas bacteria to different media suggest that, while the key regulatory elements of the T3SS are conserved, the metabolic regulation of the hrp is different in Xanthomonas spp. This differential regulation is possibly linked with the unique niche occupied by each species. It should be noted that discrepancies between the transcriptional responses of Xanthomonas to artificial plant-mimicking media and transcriptional responses within the plant environment were observed. For instance, GntR-family transcriptional regulator HpaR1/YtrA of Xcc and Xcci negatively regulates the T3SS associated genes in plant-mimicking media while positively regulates their expression in planta [63,72] (Figure 2). 
The metabolic regulation of $h r p$ gene expression is multilayered and integrates multiple environmental factors. The repression of hrp gene expression by rich undefined media suggests that the response is repressed by certain metabolites or activated by starvation. Stringent response in bacteria is induced by stress or metabolite starvation [73] and is mediated by internal levels of guanosine pentaphosphate [(p)ppGpp], which is synthesized and degraded by RelA and SpoT [73]. It was recently reported that deletion of relA and spoT homologs in Xcci completely abolished pathogenicity in citrus and caused a significant reduction in the expression of $h r p G, h r p X$, and their downstream targets [74]. Similar phenotypes were observed upon deletion of transcriptional regulator $d k s A$ [74], which is associated with alteration of the affinity of the RNA polymerase to (p)ppGpp [75] (Figure 2). These observations suggest that hrp gene expression is regulated by internal levels of (p)ppGpp that are presumably controlled by nutrient limitation. Most plantmimicking media induce hrp gene expression to a significantly higher level compared with minimal media such as M9, which is more limited in nutrients [69]. Taken together, it seems that starvation-induced stringent response is not sufficient to induce the HrpG/HrpX regulon.

Carbon sensing plays an essential role in the activation or suppression of the hrp regulon. Utilization of sucrose and fructose as the main carbon source strongly induces hrp gene expression in $\mathrm{Xeu}$, whereas such genes are not responsive to other sugars such as xylose and mannitol [69]. On the other hand, xylose appears to be a key inducer of hrp gene expression in Xoo [70]. Further studies have identified that the contribution of xylose to hrp gene expression in Xoo occurs downstream of the transcriptional regulation of hrpX. Ikawa and Tsuge reported that sucrose, galactose, fructose, and glucose promote the up-regulation of $h r p G$ and $h r p X[76,77]$, whereas structural components of the T3SS are transcriptionally upregulated specifically in the presence of xylose, presumably by stabilizing the HrpX protein [76] (Figure 2). Accordingly, deletion of the xylose responsive LacI-like transcriptional repressor $x y l R$ resulted in higher accumulation of HrpX protein and enhanced expression of T3SS structural genes as well [78] (Figure 2). The Clp/CRP transcriptional regulator is associated with cAMP-mediated carbon regulation in proteobacteria [79]. Disruption of $c l p$ in several Xanthomonas spp. abolished virulence and exoenzyme production [80-83]. A few studies suggested that Clp is indirectly associated with hrp gene regulation. For instance, Xcc clp mutant displays reduced expression of several effectors and hrp genes through the TetR transcriptional regulator FhrR [81] (Figure 2). A fhrR homolog is absent in many Xanthomonas species, such as Xeu, Xoo, Xcci, and X. citri pv. glycines (Xcg). Indeed, a second transcriptome-based study conducted in Xcg did not identify Clp-dependent hrp regulation [83]. However, the study found that $c l p$ is regulated by HrpG and HrpX in Xcg, further establishing that Clp and Hrp regulation are somewhat interconnected [83] (Figure 2).

Negative metabolic regulation by specific carbonic compounds was reported in numerous studies. Supplementation of XVM1 with TCA cycle-associated carbonic acids citrate, succinate, and pyruvate represses hrp gene expression in Xeu [69]. Exogenous supplementation of long-chain fatty acids such as oleic and myristic acids represses $h r p$ gene expression in Xcci [84]. This suppression was linked to the TetR-family transcriptional repressor TfmR that directly regulates fatty acid beta-oxidation genes in response to longchain fatty acids [84] (Figure 2). Accordingly, disruption of $t f m R$ resulted in significantly reduced virulence in citrus plants that can be partially complemented by overexpression of $h r p G$ [84].

\section{Influence of Iron and Other Metals on HrpG/HrpX Regulation}

Iron sensing, uptake, and the maintenance of intracellular iron homeostasis play a crucial part in xanthomonads virulence [85-90]. Multiple evidence supports that iron starvation plays a significant role in the regulation of the HrpG/HrpX regulon inside the host. Microarray-based transcriptome analysis showed induced expression of multiple $h r p$ genes, including $h r p G$ and $h r p X$, of Xcc under low iron conditions [91]. Further promoter probe analyses using GUS reporter fusions demonstrated upregulation of hrp gene cluster 
and $h r p G$ in Xcc under iron depletion [90]. Supplementation of exogenous iron to the $h r p$-inducing media XCM2 drastically suppresses the expression of $h r p G$ and the $h r p$ gene cluster in Xcc [71,90]. Accordingly, external supplementation of iron suppresses the HR induction on tomato leaves by Xcc and Xoc [71,90]. However, high iron availability does not affect HR induction by Xoo [90]. In addition, Xcc also displayed a drastic reduction in virulence on cabbage leaves under iron-replete condition, indicating that the pathogenicity of Xcc is activated by iron depletion [90].

Regulation of iron and metal homeostasis is multilayered and harbors several key regulators. In addition to responding to excess/depletion of iron and other metals, these regulators were shown to control many cellular functions and traits associated with pathogenicity. $\mathrm{XibR}$, an orphan response regulator, binds with ferric iron and regulates several virulenceassociated functions, including iron uptake and metabolism, T3SS and T3Es expression, chemotaxis, and motility in response to iron availability in Xcc [91]. Deletion mutant of $x i b R$ in Xcc displays a substantial reduction in both in planta colonization and virulence on cabbage [91] (Figure 2). In contrast, Ferric Uptake Regulator (Fur) binds with ferrous iron and regulates multiple cellular functions including iron homeostasis [92]. fur mutant of Xoo showed hypersensitivity to oxidative stress and reduced virulence on rice plants [85]. The Zinc Uptake Regulator (Zur) transcriptional regulator is involved in the suppression of zinc uptake to maintain cellular zinc homeostasis. This regulator was also found to indirectly upregulate $h r p X$ expression in Xcc under low iron conditions [93] (Figure 2). The ColS/ColR (VgrS/VgrR) two-component system was reported to play a critical role in iron and metal homeostasis and virulence regulation of multiple Xanthomonas spp. [58-60]. The ColS/ColR system is essential for pathogenicity and disruption of this system eliminates the ability to colonize the host and cause disease [58-60]. The ColS/ColR system was identified to respond to the availability of iron, zinc, manganese, and cadmium and was found to be critical for survival in excess/depletion of iron and other metals $[58,59,94]$. ColS is a membrane-bound receptor histidine kinase that senses extracytoplasmic iron limitation in the periplasm, while its cognate response regulator ColR detects intracellular iron excess [94]. The ColS/ColR system controls many cellular processes and pathogenicity-associated traits, such as biofilm formation, lipopolysaccharide production, catalase activity, iron uptake, tolerance to environmental stresses, and $h r p$ gene expression $[59,60,94]$ (Figure 2). Therefore, its effect on bacterial pathogenesis is multilayered and does not seem to be a result of an alteration of one particular trait. Apart from indirect transcriptional control of hrp and T3E genes, the interaction of the ColS/ColR system with the HrpG/HrpX regulon is not fully understood. The ColS sensor does not interact or directly induce the phosphorylation of HrpG and ColR-mediated interaction was not identified with the promoter sequences of $h r p G$ or $h r p X$. The transcriptional regulator $\mathrm{HpaR}$, which is positively regulated by $\operatorname{HrpG} / \mathrm{HrpX}$, was identified to directly control the colS/colR operon [57] (Figure 2). This indicates a cross-talk occurs between the col and the hrp regulons. However, such interaction still cannot fully explain downstream regulation of hrp genes by the ColS/ColR system and further study should be dedicated to the understanding of the regulatory network that connects these two regulons.

\section{Species-Specific Control of the HrpG/HrpX Regulon by Diffusible Signal Factor}

Diffusible signal factor (DSF) is a cis-unsaturated fatty acid that serves as a cell to cell signal molecule that is considered as the main quorum-sensing signal in Xanthomonadales [95]. DSF was reported to play a role in the virulence of many Xanthomonas bacteria by controlling multiple traits, including biosynthesis and dispersion of exopolysaccharides (EPS), motility, siderophore production, biofilm formation, and surface attachment [96]. DSF is sensed in recipient cells by the RpfC sensor that transmits the signal to the HD-GYP response regulator RpfG to degrade the internal signal molecule cyclic di-GMP [97]. While cell-to-cell signaling was reported to play a significant role in coordinating the expression of virulence genes in multiple pathogenic bacteria, the effect of DSF on the HrpG/HrpX regulon appears to be strain specific. Transcriptome analyses of DSF biosynthesis and 
signaling mutants in Xoo and Xcci did not identify the significant regulatory effect on $h r p G$, hrpX, or T3SS genes in artificial media [98,99], and in planta in the case of Xcci [100]. On the other hand, DSF was reported to play a role in the regulation of the hrp regulon in $X c c$. Analysis of Xcc rpfC mutant identified a significant reduction in the expression of $h r p G, h r p X$, and their downstream targets [101]. This reduction was also accompanied by reduced HR response in resistant plants and almost complete abolishment of virulence in Chinese radish [101].

\section{Transcriptional and Post-Transcriptional Regulation of $h r p G$ and $h r p X$}

Expression, stability, and activity of HrpG and HrpX are dependent on numerous regulatory factors. HrpG and HrpX are negatively or positively controlled by two-component system kinases and response regulators [60,62], ATPases [102], transcriptional regulators $[53,63,77,81,84,91,93,103-105]$, small signaling molecules [74,101] and histone-like nucleoid-structuring (H-NS) protein [106-108] (Figure 2). However, most studies do not demonstrate direct interactions with $\mathrm{HrpG}, \mathrm{HrpX}$, or their promoters and it appears that the regulatory function on this regulon by most of these factors is probably indirect.

Direct interactions between $h r p G / h r p X$ and their transcriptional regulators were reported on multiple occasions (Figure 3). Yang et al. demonstrated that the sigma factor RpoE homolog RpoE1 significantly contributes to virulence and hrp gene expression in Xcc [104] (Figure 2). Further analyses identified that RopE1 is induced in plant-mimicking media XCM1 and controls the expression of $h r p X$ in vivo [104]. RpoE1 directly binds to the $h r p X$ promoter and promotes in vitro transcription of $h r p X$, indicating that RpoE1 directly targets this regulator [104] (Figure 3). Interestingly, RpoE1 is neither affected transcriptionally by HrpG nor affects the expression of $h r p G$ itself, indicating that its regulatory function is independent of HrpG [104]. The Xcc fis-type transcriptional regulator Flp positively regulates virulence, exoenzyme production, growth in complex media, motility, and hrp gene expression [105] (Figure 2). In vivo and in vitro DNA-protein analyses combined with transcriptional data demonstrate that Flp interacts with the $h r p X$ promoter and regulates its expression, suggesting direct regulation of $h r p X$ transcription by Flp [105] (Figure 3). GamR, a LysR-type galactose metabolism regulator, was reported to regulate $h r p G$ and $h r p X$ in plant-mimicking media [77]. The regulator was found to directly bind to the $h r p G / h r p X$ intergenic region, suggesting that it is a direct regulator of the two [77] (Figure 2). However, the gamR mutant did not display any significant reduction in virulence in planta [77]. The transcriptional repressor KdgR of Xoo represses the transcription of $h r p G$ and $h r p X$ by directly binding to their promoter regions [103]. Accordingly, $k d g R$ mutant displays enhanced virulence and higher transcriptional expression of $h r p G$, $h r p X$, and $h r p$ genes [103] (Figures 2 and 3). Upstream regulation and environmental cues that affect KdgR activity remain unknown.

Post-transcriptional regulation was identified for HrpG in multiple layers. The RNA transcripts of $h r p G$ and $h r p D$ of Xcci are controlled by the CsrA/RsmA RNA-binding protein [109] by binding to the $5^{\prime}$ UTR, which consequently promotes translation and reduces transcript degradation [41] (Figure 3). Deletion mutants of $r s m A / c s r A$ in Xcc, $\mathrm{Xoo}$, and Xcci are non-pathogenic, cannot colonize their host or cause HR in resistant plants and display pleiotropic phenotypes including altered colony morphology, EPS production, motility, hydrolase activity, production of DSF, glycogen accumulation, and cell aggregation $[41,110,111]$. Transcriptome analyses showed that $r s m A / c s r A$ mutants of all three strains exhibit a significant reduction of transcript accumulation of $h r p$ and T3E genes, further supporting that the $h r p G$ is under direct control of RsmA/CsrA $[41,110,111]$ (Figure 2). E. coli RsmA/CsrA is controlled by antagonistic RNA RsmB/CsrB [112] that does not harbor any known structural homologs in xanthomonads. A potential antagonistic small RNA, RsmU (Figure 2), was recently identified in Xcc [113], but environmental cues and upstream regulators of Xanthomonas RsmA/CsrA and RsmU have yet to be identified. Intriguingly, flagellar and T4SS assembly genes, which are usually associated with epiphytic fitness, are negatively regulated by Xanthomonas RsmA/CsrA [41,114], suggesting that 
RsmA/CsrA potentially serves as a molecular switch to distinguish between the epiphytic and endophytic lifestyle of the bacteria.
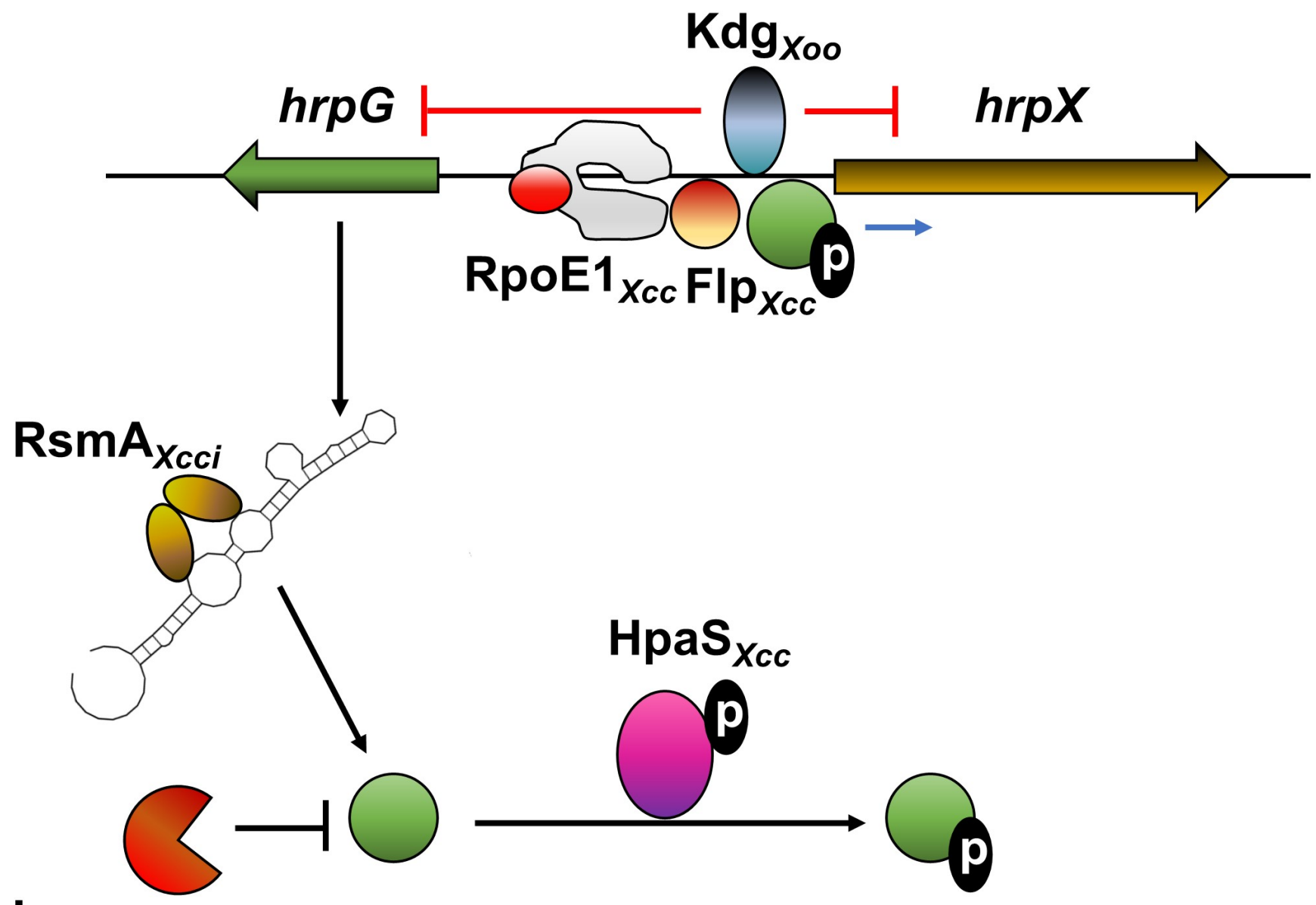

$\operatorname{Lon}_{X c c i}$

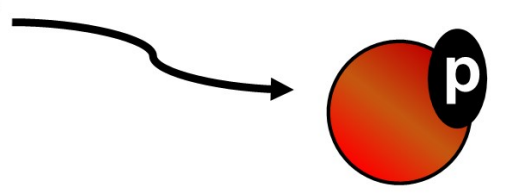

Figure 3. Schematic representation of direct transcriptional and post-transcriptional regulation of HrpG and HrpX. Red “- $\dashv$ " represents negative transcriptional regulation of $h r p G$ and $h r p X$ based on transcriptional expression and promoter binding analyses. The Blue arrow represents positive transcriptional regulation of $h r p X$ based on transcriptional expression and promoter-binding analyses. Black " $\dashv$ " and arrows represent negative and positive post-transcriptional regulation of HrpG, respectively, based on biochemical and functional analyses. Black circled "P" represents protein phosphorylation. Data represent information derived from X. citri subsp. citri (Xcci), X. oryzae pv. oryzae (Xoo), and X. campestris pv. campestris (Xcc).

Regulation of HrpG at a posttranslational level was found to be mediated by phosphorylation and protein stability. Similarly to other OmpR-family transcriptional regulators, HrpG harbors a putative phosphorylation site at position D60 [41,42,62]. The ratio of phosphorylated HrpG of Xcci is increased when bacteria are incubated in plant-mimicking media compared with rich media [41], supporting that the regulator is activated by phosphorylation. The exact signal and the sensor kinase(s) that promote HrpG phosphorylation were unknown for a significantly long period. Two hybrid studies conducted in Xcci and Xcc identified two-component sensor kinases that displayed strong interaction with HrpG [62,115]. These sensor kinases, Xcci XAC3683 and Xcc XC_3670 (HpaS), do not share significant homology or genomic localization with each other. Xcci XAC3683 was not 
subjected to any further study and its significance to the function of HrpG is unknown. The hpaS null mutant is deficient in virulence, causes attenuated HR response in resistant plants, and has reduced expression of hrp gene in plant-mimicking media and in planta [62]. Further analyses identified that HrpG phosphorylation in plant-mimicking media is dependent on HpaS, suggesting that HrpG is directly phosphorylated by HpaS in Xcc [62] (Figures 2 and 3).

The protein stability of HrpG is regulated by the Lon protease in Xcci [116] (Figure 2). Deletion of lon resulted in elevated hrp transcript accumulation, hypervirulence in host plants, and stronger HR induction in non-host plants [116]. The observed phenotypes correlate with increased stability of the HrpG protein, indicating that Lon negatively regulates HrpG [116] (Figure 3). In vitro and in vivo analyses revealed that HrpG is degraded by Lon through recognition of an N-terminal site in HrpG, which promotes its cleavage by the protease [116]. Genetic and biochemical data show that Lon activity is controlled by phosphorylation-mediated deactivation [116]. The environmental cues controlling Lon phosphorylation or the adjusted kinase that phosphorylate Lon are yet to be identified.

\section{Concluding Remarks}

Since its discovery 30 years ago, the Xanthomonas T3SS and its regulation by the HrpG/HrpX regulon were subjected to extensive study. While substantial advances were made in understanding virulence regulation in xanthomonads, many questions remain unanswered. Downstream regulation of genes other than the hrp T3SS and effector genes by HrpG/HrpX, such as the flagellum assembly genes, needs in-depth study. The upstream regulation of the HrpG/HrpX regulon is not well defined and the direct correlation between metabolic and environmental factors and functional genetic analyses needs further investigation. In addition, although it appears that the HrpG/HrpX regulon is somewhat differentially regulated between Xanthomonas spp., it remains unknown which components of the regulatory networks are global, which are species-specific, and what is the biological significance of species-specific regulation to host adaptation and specificity. Further studies dedicated to species-specific regulation of the regulon and dynamic studies of this regulation in planta may significantly improve our understanding of bacterial virulence and host specificity.

Supplementary Materials: The following are available online at https://www.mdpi.com/2076-2 607/9/1/187/s1, Figure S1: Multiple DNA sequence alignment of $h r p X$, $h r p G$, and their intragenic regions of X. euvesicatoria (Xeu) 85-10 strain (genomic region 4996282-4999333), X. citri subsp. citri (Xcci) 306 strain (genomic region 1444841-1447887), X. oryzae pv. oryzae (Xoo) KACC10331 strain (genomic region 1411025-1414008), and X. campestris pv. campestris (Xcc) 8004 strain (genomic region 3682705-3685746). Alignment was conducted using Clustal Omega under default settings (https: / / www.ebi.ac.uk/Tools/msa/clustalo/). The coding regions of $h r p G$ are marked in yellow. The coding regions of $h r p X$ are marked in green. The Start codons of $h r p G$ and $h r p X$ are marked in underlined blue. The stop codons of $h r p G$ and $h r p X$ are marked in underlined pink.

Funding: This project was supported by the US Department of Agriculture-National Institute of Food and Agriculture (USDA-NIFA) Plant Biotic Interactions Program 2017-67013-26527 and Florida Citrus Research and Development Foundation (to N.W.).

Institutional Review Board Statement: Not applicable.

Informed Consent Statement: Not applicable.

Data Availability Statement: Data sharing not applicable.

Conflicts of Interest: The authors declare no conflict of interest. 


\section{References}

1. An, S.Q.; Potnis, N.; Dow, M.; Vorhölter, F.J.; He, Y.Q.; Becker, A.; Teper, D.; Li, Y.; Wang, N.; Bleris, L.; et al. Mechanistic insights into host adaptation, virulence and epidemiology of the phytopathogen Xanthomonas. FEMS Microbiol. Rev. 2019, 44, 1-32. [CrossRef] [PubMed]

2. Timilsina, S.; Potnis, N.; Newberry, E.A.; Liyanapathiranage, P.; Iruegas-Bocardo, F.; White, F.F.; Goss, E.M.; Jones, J.B. Xanthomonas diversity, virulence and plant-pathogen interactions. Nat. Rev. Microbiol. 2020, 18, 415-427. [CrossRef] [PubMed]

3. Büttner, D.; Bonas, U. Regulation and secretion of Xanthomonas virulence factors. FEMS Microbiol. Rev. 2010, 34, 107-133. [CrossRef] [PubMed]

4. Souza, D.P.; Oka, G.U.; Alvarez-Martinez, C.E.; Bisson-Filho, A.W.; Dunger, G.; Hobeika, L.; Cavalcante, N.S.; Alegria, M.C.; Barbosa, L.R.S.; Salinas, R.K.; et al. Bacterial killing via a type IV secretion system. Nat. Commun. 2015, 6, 6453. [CrossRef]

5. Bayer-Santos, E.; Lima, L.D.P.; de Ceseti, L.M.; Ratagami, C.Y.; de Santana, E.S.; da Silva, A.M.; Farah, C.S.; Alvarez-Martinez, C.E. Xanthomonas citri T6SS mediates resistance to Dictyostelium predation and is regulated by an ECF $\sigma$ factor and cognate Ser/Thr kinase. Environ. Microbiol. 2018, 20, 1562-1575. [CrossRef]

6. Ray, S.K.; Rajeshwari, R.; Sonti, R.V. Mutants of Xanthomonas oryzae pv. oryzae deficient in general secretory pathway are virulence deficient and unable to secrete xylanase. Mol. Plant. Microbe Interact. 2000, 13, 394-401. [CrossRef]

7. Szczesny, R.; Jordan, M.; Schramm, C.; Schulz, S.; Cogez, V.; Bonas, U.; Büttner, D. Functional characterization of the Xcs and Xps type II secretion systems from the plant pathogenic bacterium Xanthomonas campestris pv vesicatoria. New Phytol. 2010, 187, 983-1002. [CrossRef]

8. Yan, Q.; Wang, N. High-throughput screening and analysis of genes of Xanthomonas citri subsp. citri involved in citrus canker symptom development. Mol. Plant. Microbe Interact. 2011, 25, 69-84. [CrossRef]

9. Solé, M.; Scheibner, F.; Hoffmeister, A.-K.; Hartmann, N.; Hause, G.; Rother, A.; Jordan, M.; Lautier, M.; Arlat, M.; Büttner, D. Xanthomonas campestris pv. vesicatoria Secretes Proteases and Xylanases via the Xps Type II Secretion System and Outer Membrane Vesicles. J. Bacteriol. 2015, 197, 2879-2893. [CrossRef]

10. Rajeshwari, R.; Jha, G.; Sonti, R.V. Role of an In Planta-Expressed Xylanase of Xanthomonas oryzae pv. oryzae in Promoting Virulence on Rice. Mol. Plant. Microbe Interact. 2005, 18, 830-837. [CrossRef]

11. Tamir-Ariel, D.; Rosenberg, T.; Navon, N.; Burdman, S. A secreted lipolytic enzyme from Xanthomonas campestris pv. vesicatoria is expressed in planta and contributes to its virulence. Mol. Plant. Pathol. 2012, 13, 556-567. [CrossRef] [PubMed]

12. Wang, L.; Rong, W.; He, C. Two Xanthomonas Extracellular Polygalacturonases, PghAxc and PghBxc, Are Regulated by Type III Secretion Regulators HrpX and HrpG and Are Required for Virulence. Mol. Plant. Microbe Interact. 2008, 21, 555-563. [CrossRef] [PubMed]

13. Jha, G.; Rajeshwari, R.; Sonti, R.V. Functional interplay between two Xanthomonas oryzae pv,. oryzae secretion systems in modulating virulence on rice. Mol. Plant. Microbe Interact. 2007, 20, 31-40. [CrossRef] [PubMed]

14. Tayi, L.; Maku, R.; Patel, H.K.; Sonti, R.V. Action of Multiple Cell Wall-Degrading Enzymes Is Required for Elicitation of Innate Immune Responses During Xanthomonas oryzae pv. oryzae Infection in Rice. Mol. Plant. Microbe Interact. 2016, $29,599-608$. [CrossRef]

15. Shen, Y.; Chern, M.; Silva, F.G.; Ronald, P. Isolation of a Xanthomonas oryzae pv. oryzae Flagellar Operon Region and Molecular Characterization of flhF. Mol. Plant. Microbe Interact. 2001, 14, 204-213. [CrossRef]

16. Malamud, F.; Torres, P.S.; Roeschlin, R.; Rigano, L.A.; Enrique, R.; Bonomi, H.R.; Castagnaro, A.P.; Marano, M.R.; Vojnov, A.A. The Xanthomonas axonopodis pv. citri flagellum is required for mature biofilm and canker development. Microbiology 2011, 157, 819-829. [CrossRef]

17. Verma, R.K.; Samal, B.; Chatterjee, S. Xanthomonas oryzae pv. oryzae chemotaxis components and chemoreceptor Mcp2 are involved in the sensing of constituents of xylem sap and contribute to the regulation of virulence-associated functions and entry into rice. Mol. Plant. Pathol. 2018, 19, 2397-2415. [CrossRef]

18. Dey, S.; Chakravarty, A.; Biswas, P.G.; De Guzman, R.N. The type III secretion system needle, tip, and translocon. Protein Sci. 2019, 28, 1582-1593. [CrossRef]

19. Tampakaki, A.P.; Skandalis, N.; Gazi, A.D.; Bastaki, M.N.; Panagiotis, F.S.; Charova, S.N.; Kokkinidis, M.; Panopoulos, N.J. Playing the "Harp": Evolution of Our Understanding of hrp/hrc Genes. Annu. Rev. Phytopathol. 2010, 48, 347-370. [CrossRef]

20. Abby, S.S.; Rocha, E.P.C. The Non-Flagellar Type III Secretion System Evolved from the Bacterial Flagellum and Diversified into Host-Cell Adapted Systems. PLoS Genet. 2012, 8, e1002983. [CrossRef]

21. White, F.F.; Potnis, N.; Jones, J.B.; Koebnik, R. The type III effectors of Xanthomonas. Mol. Plant. Pathol. 2009, 10, 749-766. [CrossRef] [PubMed]

22. Koebnik, R.; Krüger, A.; Thieme, F.; Urban, A.; Bonas, U. Specific binding of the Xanthomonas campestris pv. vesicatoria AraC-type transcriptional activator HrpX to plant-inducible promoter boxes. J. Bacteriol. 2006, 188, 7652-7660. [CrossRef] [PubMed]

23. Triplett, L.R.; Verdier, V.; Campillo, T.; Van Malderghem, C.; Cleenwerck, I.; Maes, M.; Deblais, L.; Corral, R.; Koita, O.; Cottyn, B.; et al. Characterization of a novel clade of Xanthomonas isolated from rice leaves in Mali and proposal of Xanthomonas maliensis sp. nov. Antonie Leeuwenhoek 2015, 107, 869-881. [CrossRef] [PubMed]

24. Jacobs, J.M.; Pesce, C.; Lefeuvre, P.; Koebnik, R. Comparative genomics of a cannabis pathogen reveals insight into the evolution of pathogenicity in Xanthomonas. Front. Plant. Sci. 2015, 6, 431. [CrossRef] [PubMed] 
25. Garita-Cambronero, J.; Palacio-Bielsa, A.; López, M.M.; Cubero, J. Comparative Genomic and Phenotypic Characterization of Pathogenic and Non-Pathogenic Strains of Xanthomonas arboricola Reveals Insights into the Infection Process of Bacterial Spot Disease of Stone Fruits. PLoS ONE 2016, 11, e0161977. [CrossRef]

26. Merda, D.; Briand, M.; Bosis, E.; Rousseau, C.; Portier, P.; Barret, M.; Jacques, M.; Saux, M.F.-L. Ancestral acquisitions, gene flow and multiple evolutionary trajectories of the type three secretion system and effectors in Xanthomonas plant pathogens. Mol. Ecol. 2017, 26, 5939-5952. [CrossRef]

27. Pesce, C.; Jacobs, J.M.; Berthelot, E.; Perret, M.; Vancheva, T.; Bragard, C.; Koebnik, R. Comparative Genomics Identifies a Novel Conserved Protein, HpaT, in Proteobacterial Type III Secretion Systems that Do Not Possess the Putative Translocon Protein HrpF. Front. Microbiol. 2017, 8, 1177. [CrossRef]

28. Kamoun, S.; Kado, C.I. A plant-inducible gene of Xanthomonas campestris pv. campestris encodes an exocellular component required for growth in the host and hypersensitivity on nonhosts. J. Bacteriol. 1990, 172, 5165-5172. [CrossRef]

29. Kamdar, H.V.; Kamoun, S.; Kado, C.I. Restoration of pathogenicity of avirulent Xanthomonas oryzae pv. oryzae and X. campestris pathovars by reciprocal complementation with the hrpXo and $h r p X c$ genes and identification of HrpX function by sequence analyses. J. Bacteriol. 1993, 175, 2017-2025. [CrossRef]

30. Wengelnik, K.; Bonas, U. HrpXv, an AraC-type regulator, activates expression of five of the six loci in the hrp cluster of Xanthomonas campestris pv. vesicatoria. J. Bacteriol. 1996, 178, 3462-3469. [CrossRef]

31. Martin, R.G.; Rosner, J.L. The AraC transcriptional activators. Curr. Opin. Microbiol. 2001, 4, 132-137. [CrossRef]

32. Escolar, L.; Van Den Ackerveken, G.; Pieplow, S.; Rossier, O.; Bonas, U. Type III secretion and in planta recognition of the Xanthomonas avirulence proteins AvrBs1 and AvrBsT. Mol. Plant. Pathol. 2001, 2, 287-296. [CrossRef] [PubMed]

33. Furutani, A.; Takaoka, M.; Sanada, H.; Noguchi, Y.; Oku, T.; Tsuno, K.; Ochiai, H.; Tsuge, S. Identification of Novel Type III Secretion Effectors in Xanthomonas oryzae pv. oryzae. Mol. Plant. Microbe Interact. 2009, 22, 96-106. [CrossRef] [PubMed]

34. Jiang, W.; Jiang, B.-L.; Xu, R.-Q.; Huang, J.-D.; Wei, H.-Y.; Jiang, G.-F.; Chen, W.-J.; Liu, J.; Ge, Y.-Y.; Li, G.-H.; et al. Identification of six type III effector genes with the PIP box in Xanthomonas campestris pv. campestris and five of them contribute individually to full pathogenicity. Mol. Plant. Microbe Interact. 2009, 22, 1401-1411. [CrossRef] [PubMed]

35. Wengelnik, K.; Van den Ackerveken, G.; Bonas, U. HrpG, a key hrp regulatory protein of Xanthomonas campestris pv. vesicatoria is homologous to two-component response regulators. Mol. Plant. Microbe Interact. 1996, 9, 704-712. [CrossRef] [PubMed]

36. Noel, L.; Thieme, F.; Nennstiel, D.; Bonas, U. cDNA-AFLP analysis unravels a genome-wide hrpG-regulon in the plant pathogen Xanthomonas campestris pv. vesicatoria. Mol. Microbiol. 2001, 41, 1271-1281. [CrossRef] [PubMed]

37. Guo, Y.; Figueiredo, F.; Jones, J.; Wang, N. HrpG and HrpX play global roles in coordinating different virulence traits of Xanthomonas axonopodis pv. citri. Mol. Plant. Microbe Interact. 2011, 24, 649-661. [CrossRef]

38. Ficarra, F.A.; Garofalo, C.G.; Gottig, N.; Ottado, J. The Amino Acid Arginine 210 of the Response Regulator HrpG of Xanthomonas citri subsp. citri Is Required for HrpG Function in Virulence. PLoS ONE 2015, 10, e0125516. [CrossRef]

39. Zhang, H.; Wei, J.; Qian, W.; Deng, C. Analysis of HrpG regulons and HrpG-interacting proteins by ChIP-seq and affinity proteomics in Xanthomonas campestris. Mol. Plant. Pathol. 2020, 21, 388-400. [CrossRef]

40. Itou, H.; Tanaka, I. The OmpR-Family of Proteins: Insight into the Tertiary Structure and Functions of Two-Component Regulator Proteins. J. Biochem. 2001, 129, 343-350. [CrossRef]

41. Andrade, M.O.; Farah, C.S.; Wang, N. The Post-transcriptional Regulator rsmA/csrA Activates T3SS by Stabilizing the $5^{\prime}$ UTR of hrp G, the Master Regulator of hrp/hrc Genes, in Xanthomonas. PLoS Pathog. 2014, 10, e1003945. [CrossRef] [PubMed]

42. Wengelnik, K.; Rossier, O.; Bonas, U. Mutations in the Regulatory Gene hrpG of Xanthomonas campestris pv. vesicatoria Result in Constitutive Expression of All hrp Genes. J. Bacteriol. 1999, 181, 6828-6831. [CrossRef] [PubMed]

43. Genin, S.; Gough, C.L.; Zischek, C.; Boucher, C.A. Evidence that the hrpB gene encodes a positive regulator of pathogenicity genes from Pseudomonas solanacearum. Mol. Microbiol. 1992, 6, 3065-3076. [CrossRef] [PubMed]

44. Brito, B.; Marenda, M.; Barberis, P.; Boucher, C.; Genin, S. prhJ and hrpG, two new components of the plant signal-dependent regulatory cascade controlled by PrhA in Ralstonia solanacearum. Mol. Microbiol. 1999, 31, 237-251. [CrossRef] [PubMed]

45. Lipscomb, L.; Schell, M.A. Elucidation of the Regulon and cis-Acting Regulatory Element of HrpB, the AraC-Type Regulator of a Plant Pathogen-Like Type III Secretion System in Burkholderia pseudomallei. J. Bacteriol. 2011, 193, 1991-2001. [CrossRef]

46. Zhang, X.; Zhao, M.; Yan, J.; Yang, L.; Yang, Y.; Guan, W.; Walcott, R.; Zhao, T. Involvement of $h r p X$ and $h r p G$ in the Virulence of Acidovorax citrulli Strain Aac5, Causal Agent of Bacterial Fruit Blotch in Cucurbits. Front. Microbiol. 2018, 9, 507. [CrossRef]

47. Wichmann, F.; Vorhölter, F.-J.; Hersemann, L.; Widmer, F.; Blom, J.; Niehaus, K.; Reinhard, S.; Conradin, C.; Kölliker, R. The noncanonical type III secretion system of Xanthomonas translucens pv. graminis is essential for forage grass infection. Mol. Plant. Pathol. 2013, 14, 576-588. [CrossRef]

48. Liu, Z.-Y.; Zou, L.-F.; Xue, X.-B.; Cai, L.-L.; Ma, W.-X.; Xiong, L.; Ji, Z.-Y.; Chen, G.-Y. HrcT Is a Key Component of the Type III Secretion System in Xanthomonas spp. and Also Regulates the Expression of the Key hrp Transcriptional Activator HrpX. Appl. Environ. Microbiol. 2014, 80, 3908-3919. [CrossRef]

49. Kogenaru, S.; Qing, Y.; Guo, Y.; Wang, N. RNA-seq and microarray complement each other in transcriptome profiling. BMC Genom. 2012, 13, 629. [CrossRef]

50. Roux, B.; Bolot, S.; Guy, E.; Denancé, N.; Lautier, M.; Jardinaud, M.-F.; Fischer-Le Saux, M.; Portier, P.; Jacques, M.-A.; Gagnevin, L.; et al. Genomics and transcriptomics of Xanthomonas campestris species challenge the concept of core type III effectome. BMC Genom. 2015, 16, 975. [CrossRef] 
51. Perez-Quintero, A.L.; Szurek, B. A Decade Decoded: Spies and Hackers in the History of TAL Effectors Research. Annu. Rev. Phytopathol. 2019, 57, 459-481. [CrossRef] [PubMed]

52. Bole, J.; Rongqi, X.; Xianzhen, L.; Hongyu, W.; Faan, B.; Xi, H.; Yongqiang, H.; Jiliang, T. Construction and characterization of a hrp $G$ mutant rendering constitutive expression of hrp genes in Xanthomonas campestris pv. campestris. Prog. Nat. Sci. 2006, 16, 480-485. [CrossRef]

53. Wei, K.; Tang, D.-J.; He, Y.-Q.; Feng, J.-X.; Jiang, B.-L.; Lu, G.-T.; Chen, B.; Tang, J.-L. hpaR, a Putative marR Family Transcriptional Regulator, Is Positively Controlled by HrpG and HrpX and Involved in the Pathogenesis, Hypersensitive Response, and Extracellular Protease Production of Xanthomonas campestris pathovar campestris. J. Bacteriol. 2007, 189, 2055-2062. [CrossRef] [PubMed]

54. Gómez-Gómez, L.; Boller, T. Flagellin perception: A paradigm for innate immunity. Trends Plant. Sci. 2002, 7, 251-256. [CrossRef]

55. Deochand, D.K.; Grove, A. MarR family transcription factors: Dynamic variations on a common scaffold. Crit. Rev. Biochem. Mol. Biol. 2017, 52, 595-613. [CrossRef] [PubMed]

56. Grove, A. Regulation of Metabolic Pathways by MarR Family Transcription Factors. Comput. Struct. Biotechnol. J. 2017, 15, 366-371. [CrossRef]

57. Pan, Y.; Liang, F.; Li, R.-J.; Qian, W. MarR-Family Transcription Factor HpaR Controls Expression of the vgrR-vgrS Operon of Xanthomonas campestris pv. campestris. Mol. Plant. Microbe Interact. 2018, 31, 299-310. [CrossRef]

58. Zhang, S.-S.; He, Y.-Q.; Xu, L.-M.; Chen, B.-W.; Jiang, B.-L.; Liao, J.; Cao, J.-R.; Liu, D.; Huang, Y.-Q.; Liang, X.-X.; et al. A putative colRXC1049-colSXC1050 two-component signal transduction system in Xanthomonas campestris positively regulates $h r p C$ and hrpE operons and is involved in virulence, the hypersensitive response and tolerance to various stresses. Res. Microbiol. 2008, 159, 569-578. [CrossRef]

59. Yan, Q.; Wang, N. The ColR/ColS Two-Component System Plays Multiple Roles in the Pathogenicity of the Citrus Canker Pathogen Xanthomonas citri subsp. citri. J. Bacteriol. 2011, 193, 1590-1599. [CrossRef]

60. Subramoni, S.; Pandey, A.; Priya, M.R.V.; Patel, H.K.; Sonti, R.V. The ColRS system of Xanthomonas oryzae pv. oryzae is required for virulence and growth in iron-limiting conditions. Mol. Plant. Pathol. 2012, 13, 690-703. [CrossRef]

61. Zhang, Y.; Callaway, E.; Jones, J.B.; Wilson, M. Visualisation of hrp gene expression in Xanthomonas euvesicatoria in the tomato phyllosphere. Eur. J. Plant. Pathol. 2009, 124, 379-390. [CrossRef]

62. Li, R.F.; Lu, G.T.; Li, L.; Su, H.Z.; Feng, G.F.; Chen, Y.; He, Y.Q.; Jiang, B.L.; Tang, D.J.; Tang, J.L. Identification of a putative cognate sensor kinase for the two-component response regulator HrpG, a key regulator controlling the expression of the hrp genes in Xanthomonas campestris pv. campestris. Environ. Microbiol. 2014, 16, 2053-2071. [CrossRef] [PubMed]

63. Zhou, X.; Yan, Q.; Wang, N. Deciphering the regulon of a GntR family regulator via transcriptome and ChIP-exo analyses and its contribution to virulence in Xanthomonas citri. Mol. Plant. Pathol. 2017, 18, 249-262. [CrossRef] [PubMed]

64. de Bernonville, T.D.; Noël, L.D.; Cristobal, M.S.; Danoun, S.; Becker, A.; Soreau, P.; Arlat, M.; Lauber, E. Transcriptional reprogramming and phenotypical changes associated with growth of Xanthomonas campestris pv. campestris in cabbage xylem sap. FEMS Microbiol. Ecol. 2014, 89, 527-541. [CrossRef] [PubMed]

65. Chatnaparat, T.; Prathuangwong, S.; Lindow, S.E. Global Pattern of Gene Expression of Xanthomonas axonopodis pv. glycines Within Soybean Leaves. Mol. Plant. Microbe Interact. 2016, 29, 508-522. [CrossRef] [PubMed]

66. Hu, Y.; Zhang, J.; Jia, H.; Sosso, D.; Li, T.; Frommer, W.B.; Yang, B.; White, F.F.; Wang, N.; Jones, J.B. Lateral organ boundaries 1 is a disease susceptibility gene for citrus bacterial canker disease. Proc. Natl. Acad. Sci. USA 2014, 111, E521-E529. [CrossRef]

67. Zhou, X.; Hu, X.; Li, J.; Wang, N. A Novel Periplasmic Protein, VrpA, Contributes to Efficient Protein Secretion by the Type III Secretion System in Xanthomonas spp. Mol. Plant. Microbe Interact. 2015, 28, 143-153. [CrossRef]

68. Kim, S.; Cho, Y.-J.; Song, E.-S.; Lee, S.H.; Kim, J.-G.; Kang, L.-W. Time-resolved pathogenic gene expression analysis of the plant pathogen Xanthomonas oryzae pv. oryzae. BMC Genom. 2016, 17, 345. [CrossRef]

69. Schulte, R. A Xanthomonas Pathogenicity Locus Is Induced by Sucrose and Sulfur-Containing Amino Acids. Plant. Cell 1992, 4, 79-86. [CrossRef]

70. Tsuge, S.; Furutai, A.; Fukunaka, R.; Oku, T.; Tsuno, K.; Ochiai, H.; Inoue, Y.; Kaku, H.; Kubo, Y. Expression of Xanthomonas oryzae pv. oryzae hrp Genes in XOM2, a Novel Synthetic Medium. J. Gen. Plant. Pathol. 2002, 68, 363-371. [CrossRef]

71. Jiang, G.F.; Le Jiang, B.; Yang, M.; Liu, S.; Liu, J.; Liang, X.X.; Bai, X.F.; Tang, D.J.; Lu, G.T.; He, Y.Q.; et al. Establishment of an inducing medium for type III effector secretion in Xanthomonas campestris pv. campestris. Braz. J. Microbiol. 2013, 44, 945-952. [CrossRef] [PubMed]

72. An, S.-Q.; Lu, G.-T.; Su, H.-Z.; Li, R.-F.; He, Y.-Q.; Jiang, B.-L.; Tang, D.-J.; Tang, J.-L. Systematic Mutagenesis of All Predicted gntR Genes in Xanthomonas campestris pv. campestris Reveals a GntR Family Transcriptional Regulator Controlling Hypersensitive Response and Virulence. Mol. Plant. Microbe Interact. 2011, 24, 1027-1039. [CrossRef] [PubMed]

73. Irving, S.E.; Choudhury, N.R.; Corrigan, R.M. The stringent response and physiological roles of (pp)pGpp in bacteria. Nat. Rev. Microbiol. 2020, 1-16. [CrossRef]

74. Zhang, Y.; Teper, D.; Xu, J.; Wang, N. Stringent response regulators (p)ppGpp and DksA positively regulate virulence and host adaptation of Xanthomonas citri. Mol. Plant. Pathol. 2019, 20, 1550-1565. [CrossRef] [PubMed]

75. Sanchez-Vazquez, P.; Dewey, C.N.; Kitten, N.; Ross, W.; Gourse, R.L. Genome-wide effects on Escherichia coli transcription from ppGpp binding to its two sites on RNA polymerase. Proc. Natl. Acad. Sci. USA 2019, 116, 8310-8319. [CrossRef] [PubMed] 
76. Ikawa, Y.; Tsuge, S. The quantitative regulation of the hrp regulator HrpX is involved in sugar-source-dependent hrp gene expression in Xanthomonas oryzae pv. oryzae. FEMS Microbiol. Lett. 2016, 363, fnw071. [CrossRef] [PubMed]

77. Rashid, M.M.; Ikawa, Y.; Tsuge, S. GamR, the LysR-type galactose metabolism regulator, regulates hrp gene expression via transcriptional activation of two key hrp regulators, HrpG and HrpX, in Xanthomonas oryzae pv. oryzae. Appl. Environ. Microbiol. 2016, 82, 3947-3958. [CrossRef] [PubMed]

78. Ikawa, Y.; Ohnishi, S.; Shoji, A.; Furutani, A.; Tsuge, S. Concomitant Regulation by a LacI-Type Transcriptional Repressor XylR on Genes Involved in Xylan and Xylose Metabolism and the Type III Secretion System in Rice Pathogen Xanthomonas oryzae pv. oryzae. Mol. Plant. Microbe Interact. 2018, 31, 605-613. [CrossRef]

79. Soberón-Chávez, G.; Alcaraz, L.D.; Morales, E.; Ponce-Soto, G.Y.; Servín-González, L. The Transcriptional Regulators of the CRP Family Regulate Different Essential Bacterial Functions and Can Be Inherited Vertically and Horizontally. Front. Microbiol. 2017, 8, 959. [CrossRef]

80. de Crecy-Lagard, V.; Glaser, P.; Lejeune, P.; Sismeiro, O.; Barber, C.E.; Daniels, M.J.; Danchin, A. A Xanthomonas campestris pv. campestris protein similar to catabolite activation factor is involved in regulation of phytopathogenicity. J. Bacteriol. 1990, 172, 5877-5883. [CrossRef]

81. He, Y.-W.; Ng, A.Y.-J.; Xu, M.; Lin, K.; Wang, L.-H.; Dong, Y.-H.; Zhang, L.-H. Xanthomonas campestris cell-cell communication involves a putative nucleotide receptor protein Clp and a hierarchical signalling network. Mol. Microbiol. 2007, 64, 281-292. [CrossRef] [PubMed]

82. Wang, B.; Wu, G.; Zhang, Y.; Qian, G.; Liu, F. Dissecting the virulence-related functionality and cellular transcription mechanism of a conserved hypothetical protein in Xanthomonas oryzae pv. oryzae. Mol. Plant. Pathol. 2018, 19, 1859-1872. [CrossRef] [PubMed]

83. Guo, W.; Gao, J.; Chen, Q.; Ma, B.; Fang, Y.; Liu, X.; Chen, G.; Liu, J.-Z. Crp-Like Protein Plays Both Positive and Negative Roles in Regulating the Pathogenicity of Bacterial Pustule Pathogen Xanthomonas axonopodis pv. glycines. Phytopathol. 2019, 109, 1171-1183. [CrossRef] [PubMed]

84. Teper, D.; Zhang, Y.; Wang, N. TfmR, a novel TetR-family transcriptional regulator, modulates the virulence of Xanthomonas citri in response to fatty acids. Mol. Plant. Pathol. 2019, 20, 701-715. [CrossRef]

85. Subramoni, S.; Sonti, R.V. Growth Deficiency of a Xanthomonas oryzae pv. oryzae fur Mutant in Rice Leaves Is Rescued by Ascorbic Acid Supplementation. Mol. Plant. Microbe Interact. 2005, 18, 644-651. [CrossRef]

86. Pandey, A.; Sonti, R.V. Role of the FeoB Protein and Siderophore in Promoting Virulence of Xanthomonas oryzae pv. oryzae on Rice. J. Bacteriol. 2010, 192, 3187-3203. [CrossRef]

87. Rai, R.; Javvadi, S.; Chatterjee, S. Cell-cell signalling promotes ferric iron uptake in Xanthomonas oryzae pv. oryzicola that contribute to its virulence and growth inside rice. Mol. Microbiol. 2015, 96, 708-727. [CrossRef]

88. Pandey, S.S.; Patnana, P.K.; Rai, R.; Chatterjee, S. Xanthoferrin, the $\alpha$-hydroxycarboxylate-type siderophore of Xanthomonas campestris pv. campestris, is required for optimum virulence and growth inside cabbage. Mol. Plant. Pathol. 2017, 18, 949-962. [CrossRef]

89. Javvadi, S.; Pandey, S.S.; Mishra, A.; Pradhan, B.B.; Chatterjee, S. Bacterial cyclic $\beta$-(1,2)-glucans sequester iron to protect against iron-induced toxicity. EMBO Rep. 2018, 19, 172-186. [CrossRef]

90. Pandey, S.S.; Patnana, P.K.; Padhi, Y.; Chatterjee, S. Low-iron conditions induces the hypersensitive reaction and pathogenicity hrp genes expression in Xanthomonas and is involved in modulation of hypersensitive response and virulence. Environ. Microbiol. Rep. 2018, 10, 522-531. [CrossRef]

91. Pandey, S.S.; Patnana, P.K.; Lomada, S.K.; Tomar, A.; Chatterjee, S. Co-regulation of Iron Metabolism and Virulence Associated Functions by Iron and XibR, a Novel Iron Binding Transcription Factor, in the Plant Pathogen Xanthomonas. PLoS Pathog. 2016, 12, e1006019. [CrossRef] [PubMed]

92. Escolar, L.; Pérez-Martín, J.; de Lorenzo, V. Opening the Iron Box: Transcriptional Metalloregulation by the Fur Protein. J. Bacteriol. 1999, 181, 6223-6229. [CrossRef] [PubMed]

93. Huang, D.-L.; Tang, D.-J.; Liao, Q.; Li, X.-Q.; He, Y.-Q.; Feng, J.-X.; Jiang, B.-L.; Lu, G.-T.; Tang, J.-L. The Zur of Xanthomonas campestris Is Involved in Hypersensitive Response and Positively Regulates the Expression of the hrp Cluster Via hrpX But Not hrp G. Mol. Plant. Microbe Interact. 2009, 22, 321-329. [CrossRef] [PubMed]

94. Wang, L.; Pan, Y.; Yuan, Z.-H.; Zhang, H.; Peng, B.-Y.; Wang, F.-F.; Qian, W. Two-Component Signaling System VgrRS Directly Senses Extracytoplasmic and Intracellular Iron to Control Bacterial Adaptation under Iron Depleted Stress. PLoS Pathog. 2016, 12, e1006133. [CrossRef]

95. Dow, J.M. Diffusible signal factor-dependent quorum sensing in pathogenic bacteria and its exploitation for disease control. J. Appl. Microbiol. 2017, 122, 2-11. [CrossRef]

96. Ryan, R.P.; An, S.; Allan, J.H.; McCarthy, Y.; Dow, J.M. The DSF Family of Cell-Cell Signals: An Expanding Class of Bacterial Virulence Regulators. PLoS Pathog. 2015, 11, e1004986. [CrossRef]

97. He, Y.-W.; Zhang, L.-H. Quorum sensing and virulence regulation in Xanthomonas campestris. FEMS Microbiol. Rev. 2008, 32, 842-857. [CrossRef]

98. Rai, R.; Ranjan, M.; Pradhan, B.B.; Chatterjee, S. Atypical regulation of virulence-associated functions by a diffusible signal factor in Xanthomonas oryzae pv. oryzae. Mol. Plant. Microbe Interact. 2012, 25, 789-801. [CrossRef] 
99. Guo, Y.; Zhang, Y.; Li, J.-L.; Wang, N. Diffusible signal factor-mediated quorum sensing plays a central role in coordinating gene expression of Xanthomonas citri subsp. citri. Mol. Plant. Microbe Interact. 2012, 25, 165-179. [CrossRef]

100. Li, L.; Li, J.; Zhang, Y.; Wang, N. Diffusible signal factor (DSF)-mediated quorum sensing modulates expression of diverse traits in Xanthomonas citri and responses of citrus plants to promote disease. BMC Genom. 2019, 20, 55. [CrossRef]

101. Jiang, B.-L.; Jiang, G.-F.; Liu, W.; Yang, L.-C.; Yang, L.-Y.; Wang, L.; Hang, X.-H.; Tang, J.-L. RpfC regulates the expression of the key regulator hrpX of the hrp/T3SS system in Xanthomonas campestris pv. campestris. BMC Microbiol. 2018, 18, 103. [CrossRef] [PubMed]

102. Cui, P.; Li, R.-F.; Zhang, D.-P.; Tang, J.-L.; Lu, G.-T. HpaP, a novel regulatory protein with ATPase and phosphatase activity, contributes to full virulence in Xanthomonas campestris pv. campestris. Environ. Microbiol. 2018, 20, 1389-1404. [CrossRef] [PubMed]

103. Lu, Y.; Rashidul, I.M.; Hirata, H.; Tsuyumu, S. KdgR, an ICIR family transcriptional regulator, inhibits virulence mainly by repression of hrp genes in Xanthomonas oryzae pv. oryzae. J. Bacteriol. 2011, 193, 6674-6682. [CrossRef] [PubMed]

104. Yang, L.-Y.; Yang, L.-C.; Gan, Y.-L.; Wang, L.; Zhao, W.-Z.; He, Y.-Q.; Jiang, W.; Jiang, B.-L.; Tang, J.-L. Systematic Functional Analysis of Sigma $(\sigma)$ Factors in the Phytopathogen Xanthomonas campestris Reveals Novel Roles in the Regulation of Virulence and Viability. Front. Microbiol. 2018, 9, 1749. [CrossRef] [PubMed]

105. Leng, M.; Lu, Z.; Qin, Z.; Qi, Y.; Lu, G.; Tang, J. Flp, a Fis-like protein, contributes to the regulation of type III secretion and virulence processes in the phytopathogen Xanthomonas campestris pv. campestris. Mol. Plant. Pathol. 2019, 1119-1133. [CrossRef]

106. Feng, J.-X.; Song, Z.-Z.; Duan, C.-J.; Zhao, S.; Wu, Y.-Q.; Wang, C.; Dow, J.M.; Tang, J.-L. The xrvA gene of Xanthomonas oryzae pv. oryzae, encoding an H-NS-like protein, regulates virulence in rice. Microbiology 2009, 155, 3033-3044. [CrossRef] [PubMed]

107. Kametani-Ikawa, Y.; Tsuge, S.; Furutani, A.; Ochiai, H. An H-NS-like protein involved in the negative regulation of hrp genes in Xanthomonas oryzae pv. oryzae. FEMS Microbiol. Lett. 2011, 319, 58-64. [CrossRef]

108. Liu, Y.; Long, J.; Shen, D.; Song, C. Xanthomonas oryzae pv. oryzae requires H-NS-family protein XrvC to regulate virulence during rice infection. FEMS Microbiol. Lett. 2016, 363, fnw067. [CrossRef]

109. Storz, G.; Papenfort, K. Global Regulation by CsrA and Its RNA Antagonists. In Regulating with RNA in Bacteria and Archaea; American Society of Microbiology: Washington, DC, USA, 2019; pp. 341-354.

110. Chao, N.-X.; Wei, K.; Chen, Q.; Meng, Q.-L.; Tang, D.-J.; He, Y.-Q.; Lu, G.-T.; Jiang, B.-L.; Liang, X.-X.; Feng, J.-X.; et al. The rsmA -like Gene rsmA Xcc of Xanthomonas campestris pv. campestris Is Involved in the Control of Various Cellular Processes, Including Pathogenesis. Mol. Plant. Microbe Interact. 2008, 21, 411-423. [CrossRef]

111. Zhu, P.-L.; Zhao, S.; Tang, J.-L.; Feng, J.-X. The rsmA-like gene rsmAXoo of Xanthomonas oryzae pv. oryzae regulates bacterial virulence and production of diffusible signal factor. Mol. Plant. Pathol. 2011, 12, 227-237. [CrossRef]

112. Pourciau, C.; Lai, Y.-J.; Gorelik, M.; Babitzke, P.; Romeo, T. Diverse Mechanisms and Circuitry for Global Regulation by the RNA-Binding Protein CsrA. Front. Microbiol. 2020, 11, 601352. [CrossRef] [PubMed]

113. Tang, D.; Chen, X.; Jia, Y.; Liang, Y.; He, Y.; Lu, T.; Zhu, C.; Han, B.; An, S.; Tang, J. Genome-wide screen and functional analysis in Xanthomonas reveal a large number of mRNA-derived sRNAs, including the novel RsmA-sequester RsmU. Mol. Plant. Pathol. 2020, 21, 1573-1590. [CrossRef] [PubMed]

114. Cenens, W.; Andrade, M.O.; Llontop, E.; Alvarez-Martinez, C.E.; Sgro, G.G.; Farah, C.S. Bactericidal type IV secretion system homeostasis in Xanthomonas citri. PLoS Pathog. 2020, 16, e1008561. [CrossRef] [PubMed]

115. Alegria, M.C.; Docena, C.; Khater, L.; Ramos, C.H.I.; da Silva, A.C.R.; Farah, C.S. New Protein-Protein Interactions Identified for the Regulatory and Structural Components and Substrates of the Type III Secretion System of the Phytopathogen Xanthomonas axonopodis pathovar citri. J. Bacteriol. 2004, 186, 6186-6197. [CrossRef]

116. Zhou, X.; Teper, D.; Andrade, M.O.; Zhang, T.; Chen, S.; Song, W.-Y.; Wang, N. A Phosphorylation Switch on Lon Protease Regulates Bacterial Type III Secretion System in Host. MBio 2018, 9, e02146-17. [CrossRef] 